\title{
A Reflection on the Online Lectures
}

Gracia M. N. Otta

Lecturer of English Department of Nusa Cendana University, Kupang, East Nusa Tenggara, Indonesia

Corresponding Author: Gracia M. N. Otta, E-mail: graciaotta@gmail.com

\section{ARTICLE INFORMATION}

Received: August 12, 2020

Accepted: September 22, 2020

Volume: 3

Issue: 9

DOI: $10.32996 / \mathrm{ijl} \mid \mathrm{t} .2020 .3 .9 .21$

\section{KEYWORDS}

Online learning, Face-to-face learning, Students' perceptions, students' expectations, Learning Management System (LMS)

\section{ABSTRACT}

The phenomenon of Coronavirus Disease 2019 forced the education system in Indonesia to be run online. The descriptive qualitative method was used in this research to investigate some cases faced by the Fourth Semester Students of the English Department, Nusa Cendana University toward online learning in CrossCultural Communication Lecture. It was conducted to answer students' perceptions, solutions, and expectations in joining online lectures for the last three months in the Even Semester of Academic Year 2019-2020. To collect the data, and a nonfacial interview technique was applied through some online Learning Management System; e-learning by Nusa Cendana University and Google Classroom. The data were analyzed by categorizing the students' answers. The result of this study showed that $11.43 \%$ were ready for online lectures, while those who prefer regular classes were $82.86 \%$. Only $27.14 \%$ could meet the needs of online lectures since they had available mobile data, while $47.14 \%$ frankly stated having mobile data problem. It can be concluded that there were some changes in learning culture that forced students to deal with online teaching-learning activities. Undeniable, it was not easy to organize except well prepared from the very first beginning of class by having Course Contract which only needed to be changed into an online form. Yet, their expectations for universities and government to increase Learning Management System and subsidies for the needs of mobile data bundle (for teachers, lecturers, and students).

\section{Introduction}

The coronavirus 2019 pandemic has changed several activities of humans live all over the world. It was prohibited to go out of the house and to have face-to-face interactions in order to break the chain of the virus spread. The concept of face-to-face education has also changed. It suddenly turned to be online lectures. What about the anticipation of lecturers, teachers, and students in dealing with online classes during Even Semester 2019-2020 in Indonesia? It is acceptable to apply to schools and universities with adequate network facilities. In reality, it was difficult for those who live in rural and remote areas to have online teaching and learning.

Modifying face-to-face based teaching-learning to online methods absolutely requires availability in financial and resources. For lecturers, teachers, students, schools, and universities who are familiar with technology and online-based education, absolutely not a big problem, only several changes to be an online form. On the other hand, it might be difficult for those institutions with a lack of technology access.

The art of teaching, whether to have face-to-face or online meetings is dialogue. Regardless of the methods and tools used in both systems, a dialogue is the essence that should be considered. The problem of this case study is about students' perceptions, solutions, and expectations for online lecturers.

K C AL-KINDI CENTER

R D FOR RESEARCH AND $\mathbf{R} \mathbf{D}$ DEVELOPMENT Your gateway to world-class research
Published by Al-KindiCenter for Research and Development. Copyright (c) the author(s). This is an open access article under CC BY license (https://creativecommons.org/licenses/by/4.0/) 


\section{Literature Review}

Back in March 2020, the education system in Indonesia was forced to be run online due to the prevention of coronavirus disease. It also affected the teaching-learning system in East Nusa Tenggara Province. Basically, not all school has already maintained online teaching-learning system. It is finally necessary to be carried out from basic, secondary, as well as higher education in order to deliver material by using various platforms.

In line with that, online learning has become popular because of its potential for providing more flexible access to content and instruction at any time, from any place. Frequently, the focus entails (a) increasing the availability of learning experiences for learners who cannot or choose not to attend traditional face-to-face offerings, (b) assembling and disseminating instructional content more cost-efficiently, or (c) enabling instructors to handle more students while maintaining learning outcome quality that is equivalent to that of comparable face-to-face instruction. (Means et.al, 2010).

In addition, Means (2010) stated that "Different technology applications are used to support different models of online learning. One class of online learning models uses asynchronous communication tools (e.g., e-mail, threaded discussion boards, newsgroups) to allow users to contribute at their convenience". Synchronous technologies (e.g., webcasting, chat rooms, desktop audio/video technology) are used to approximate face-to-face teaching strategies such as delivering lectures and holding meetings with groups of students. Earlier online programs tended to implement one model or the other. More recent applications tend to combine multiple forms of synchronous and asynchronous online interactions as well as occasional face-to-face interactions.

The benefit of flexibility in online courses cannot be overstated due to its prevalence in the reasons why students are attracted to online learning. Online learning allows students to work at a time and a place that is compatible with their learning needs. A number of instructors and students commented on their ability to focus more of their attention on the content of the course and less on issues such as parking, traffic, and other problems that may arise when attending a traditional class environment (Thomson,2010).

Technology is an area that can be easily taken for granted when it is intertwined into daily life, but for many, technology is not vastly used due to the lack of monetary means to gain access. (Chaney, 2001, p. 28). In reality, it also became a specific case for students in rural and remote areas who possessed limited access to technology and communication that made them met obstacles in running online-based teaching-learning.

The use of media technology in the 21st century has become a demand and necessity for every teacher to encourage students to study independently, collaboratively, creatively, and critically in solving problems. Although technology has been widely used in various educational institutions, it still has several limitations such as ignoring direct physical interaction among students, and the assessment conducted by lecturers is only done through an online platform called e-learning (Asfar and Zainuddin, 2016; Kanuka \& Anderson, 2007).

In e-learning, the learning only focuses on the online or long-distance interaction without face-to-face interaction. Online learning only limits the instructor or teacher to assess virtually. However, the face-to-face learning model plays an important role where the instructor or teacher could interact with students physically and emotionally (Sun, et al., 2008). Related to that, teachers in certain areas in East Nusa Tenggara still managed the traditional system in a pandemic situation. They visited students' houses since it was difficult for students to deal with internet access even technology devices such as mobile phones and laptops.

Computer Assisted Language Learning (CALL) technologies and Learning Management Systems (LMS) continue to advance in sophistication. However, some researchers question aspects of their suitability for higher education and language teaching.(Naidu, 2006; Wright, 2017).

An LMS is a web-based or cloud-based software program which assist in teaching-learning process and helps in the effective delivery of instruction, training, and development program.LMS, widely spread and, hence the use of this acronym in this study may be defined, in the user perspective, as a virtual environment that aims to simulate face-to-face learning environments with the use of Information Technology. 
LMS's functions in higher education instruction and classified them as: first, a course-organizing tool, such as a replacement to a traditional syllabus, grade books, and testing tools; second, a dynamic tool to facilitate the process of learning, such as synchronous and asynchronous discussion groups; and third, a space to enhance student collaboration (Landsberger, 2004). In an LMS, the interaction happens through devices that enable communication either synchronously or asynchronously, allowing the creation of different strategies to encourage a dialogue and active participation of students. Other popular names which are used interchangeably in the place of Learning Management System are Personal Learning environment (PLE), Course Management System (CMS), Virtual Learning Environment (VLE), E- Learning Courseware and Training Management system (TMS) where TMS is widely used in industries and business purpose and rest in terms like PLE, CMS, and VLE mostly serves the educational field (Araújo-Junior \& Marquesi, 2009; Chaubey \& Bhattacharya, 2015).

LMS also provides tools for multimedia contents, assignments, and supporting interaction, including discussion groups, chat sessions, and online quizzes and examinations. Bonk and Graham (2006) discussed the benefits of online learning which can be categorized into three aspects: first is Pedagogical Improvement. Each LMS follows more or less some pedagogical strategy regardless of whether developers used it intentionally or not. However, only some LMSs seem to be built intentionally based on specific pedagogical strategies. Second is about Increasing of Access and Flexibility. Access is one of the most important key factors which influence the growth of learning environments, LMS makes learning possible, even when learners have most of their learning experiences far from instructors or other learners. Third is Cost-Effectiveness. Online learning is one of the best solutions in cost-effectiveness in higher education as it provides an opportunity for reaching a large, globally dispersed audience in a short period of time with consistent content delivery.

Recently, the use of LMS as teaching-learning media in East Nusa Tenggara is increasing in diverse platforms. Some used Zoom Cloud meeting, Google Classroom, Google Meet, Cisco Webex Meetings, e-learning tools provided by Universities and etcetera.

Online learning is a form of distance learning or distance education, which has long been a part of the American education system and it has become the largest sector of distance learning in recent years(Bartley \& Golek, 2004; Evans \& Haase, 2001). Online learning is a form of distance learning or distance education, which has long been a part of the American education system, and it has become the largest sector of distance learning in recent years(Bartley \& Golek, 2004; Evans \& Haase, 2001).It is obvious that changing the learning culture is not easy. There are obstacles in managing online teaching-learning and especially related to technology-based activities. It is inseparable from the availability of electronic devices and networks, which not all students have and can access from their learning places.

\section{Methods}

This study was designed to analyze students' perceptions, expectations, and dictions used to express their feelings toward online teaching-learning in a pandemic situation during March - June 2020.This case study, based on the students being interviewed, focused on the Fourth semester who were currently enrolled in the Cross-Cultural Communication course.

Qualitative research is related to interpretation and naturalistic approach where the researchers work on natural phenomena. It also described several assumptions, theories, and the evaluation of specific principles practice or innovations (Denzin and Lincoln, 2000:3; Leedy and Omrod, 2005).

Data was found in this study through a non-facial interview by using e-learning by Nusa Cendana University. It was distributed to the students enrolled in the course as the Final Test. There were two classes that consist of seventy students.

The writer analyzed students' answer qualitatively based on four questions about the perceptions, strategies, and solutions in online teaching-learning activities and one question about their observation of cultural changes before, during, and after the coronavirus 2019 disease spread.

\section{Findings and Discussion}

In this study, students were asked to give their perceptions, expectations, and solutions through five questions. First, students were asked to give opinions on which is better, to join face-to-face or online classes. It deals with their opinions among all subjects they take during three months of stay at home learning in Even Semester 2019-2020. Second, they needed 
to reveal their argument over a statement that online and traditional teachings are different concepts. Third was about the skills they should obtain in a new learning culture. Fourth, they had to give solutions for online learning especially for those who met obstacles during online classes. And the last, they compared cultural changes through various phenomena lately based on their observation due to the current situation in the world, or in Indonesia, or in Kupang, or in their hometown.

The results showed that the number of students who agreed to online classes was $11.43 \%$, while those who prefer regular classes were $82.86 \%$. By seeing this, it can be stated that by enrolling online classes made them met obstacles therefore, face-to-face learning was the best selection at that time. In the middle of the opinions, there were $4.29 \%$ who agreed to both online and regular classes. Unfortunately, $1.42 \%$ did not respond to the question.

In giving their opinions, they also emphasized some obstacles faced which related to the availability of the network where they studied. As for more information, during the pandemic situation and when this interview took place, not all students were staying in Kupang town. Some of them went back to their hometown to save living costs. In addition, mobile data limitation also became a serious problem among them. Even some of them did not have smartphones or laptops. Only $27.14 \%$ could meet the needs of online classes since they had available mobile data while $47.14 \%$ frankly stated having mobile data problems. In relation to that, $11.43 \%$ mentioned they were able to provide mobile data but prefer regular classes. The rest of $14.29 \%$ did not respond about it.

Furthermore, students gave their opinions on what skills were improved during the online learning process. Among seven skills, the quality of Information and Communications Technology (ICT). It included their skills in video making and editing. It was the highest percentage in this study which was $47.43 \%$ followed by $22.29 \%$ stated about time management. While the lowest one was $0.43 \%$ for those who did not give any answer for this. In relation to that, they also revealed some other skills, as $12.71 \%$ of students upgraded their skill to learn independently where they tried to find appropriate sources to learn English skills (Listening, Reading, Speaking, and Writing). Communication skill was also one of the students' capabilities which improved here. There was $7.14 \%$ of them mentioned this. They also learned to be more creative, innovative, and built critical thinking in every assignment given, which showed in $5.71 \%$ of their answers. As the closing, there was $4.29 \%$ students mentioned self-control where they needed to be more patient and responsible for their commitment as students in the university.

Regarding the accuracy in distinguishing traditional and online classes, students explained there were differences between those terms along with the advantages and disadvantages of each learning system. Most of them agreed that face-to-face learning is much better than online learning where the lecturer can do much more creative stuff and can organize and control students' activities directly.

As for the solutions, $48.85 \%$ stated that to build communication with the lecturers could help them to get more understanding about materials and tasks. Finding more information about courses' requirements from the lecturers and friends was also important as $21.42 \%$ of them gave this idea. Some of them also said that to be patients and follow the rules were also needed in this situation, as $12.85 \%$ of them responded. In order to maintain the friendship, $11.42 \%$ did not have problems in sharing hotspots. Among those solutions, $5.71 \%$ decided to request for an extra budget from their parents to fulfill online class tasks. While $5.71 \%$ of those students did not give solutions that regarding these matters.

This situation made the students expected more from the university and government of East Nusa Tenggara regarding obstacles in facing online learning. As one of the solutions, Nusa Cendana University has provided E-Learning as a Learning Management System for lecturers and students to complete teaching-learning activities. Actually, it is familiar to Nusa Cendana University in maintaining its LMS for lecturers and students. Yet, it became a problem for students with a lack of access and gadgets.

Another finding revealed by the writer was about cultural changes before and after coronavirus spread. In collaboration with students' answers, it can be showed that the pandemic situation and condition has made some cultural changes in people's daily life as presented in Table.1: 
Table.1 Cultural changes during the pandemic in East Nusa Tenggara based on students' observation

\begin{tabular}{|l|l|l|}
\hline \multicolumn{1}{|c|}{ Social features } & \multicolumn{1}{|c|}{ Before pandemic } & \multicolumn{1}{c|}{ During pandemic } \\
\hline Greetings & Shake hands and rub the nose & $\begin{array}{l}\text { Bow and put hands on the } \\
\text { chest }\end{array}$ \\
\hline Teaching-learning activities & $\begin{array}{l}\text { No social and physical distancing } \\
\text { rules }\end{array}$ & $\begin{array}{l}\text { Social distancing, physical } \\
\text { distancing rules }\end{array}$ \\
\hline Social media posts & Photos in tourism places & $\begin{array}{l}\text { Home situation, homemade } \\
\text { food, quarantine activities }\end{array}$ \\
\hline Personal activities & As easy as it could be done & $\begin{array}{l}\text { More preparation such as to } \\
\text { wear mask and always bring } \\
\text { hand sanitizer, avoid crowded } \\
\text { places, not leaving home for } \\
\text { urgent matters only, wash } \\
\text { hand and take shower after } \\
\text { reaching home }\end{array}$ \\
\hline Economy & $\begin{array}{l}\text { Stable, shops are open } \\
\text { everywhere }\end{array}$ & $\begin{array}{l}\text { Reduce as people were } \\
\text { instructed to stay and work } \\
\text { from home, shops are close in } \\
\text { certain areas }\end{array}$ \\
\hline Cultural and religious activity & $\begin{array}{l}\text { Stable and } \\
\text { everywhere }\end{array}$ & $\begin{array}{l}\text { It was prohibited to celebrate } \\
\text { any kind of cultural activity, } \\
\text { even worship activities were } \\
\text { instructed to be done from } \\
\text { home }\end{array}$ \\
\hline
\end{tabular}

In line with things mentioned, there are still various kind of socio-cultural problems related to the spread of the coronavirus which can cause long-term problems.

\section{Conclusions}

Based on the findings on students' perceptions, expectations, and solutions, it can be concluded that there were some changes in learning culture that forced students to deal with online teaching-learning activities. Undeniable, it was not easy to organize. Fortunately, the writer had provided an offline Course Contract which then modified to be run online and it was organized to be project-based lectures.

Although online classes have been applied before, still students encountered problems related to the availability of gadgets and mobile data. In addition, socio-cultural problems have also changed in line with the spread of the coronavirus 2019. Economy factors also became a matter of linked to students' need for more budgets in doing online lectures. The writer suggested for other researchers to investigate more phenomena on the online lectures that concerns teaching strategies, students' participations, or students' interests in the online lectures.

\section{Acknowledgments}

The writer would like to express her sincere gratitude to all the Fourth Semester students in Class $G$ and $H$ who took the Cross-Cultural Communication Lecture for their participation and willingness, to the amazing proofreader, and also to special people for their genuine assistance. 


\section{References}

[1] Araújo -Junior C.F., Marquesi S.C. (2009). Atividades em ambientes virtuais de aprendizagem: Parâmetros de qualidade. In: LITTO, F.M., \& Formiga, M. (Eds.), Educação a distância:o estado da arte. Pearson, São Paulo p.358 -368.

[2] Asfar, N., \& Zainuddin, Z. (2015). Secondary students' perceptions of information, communication, and technology (ICT) use in promoting self-directed learning in Malaysia. The Online Journal of Distance Education and E-Learning, 3 (4), 67-82.

[3] Chaney, E. G. (2001). Web-based instruction in a rural high school: A collaborative inquiry into its effectiveness and desirability. NASSP Bulletin, 85(628), 20-35.

[4] Denzin N. and Lincoln Y. (Eds.) (2000). Handbook of Qualitative Research.. London: Sage Publication Inc.

[5] Gilbert, B. (2015). Online learning revealing the benefits and challenges.

[6] Habeeb, K.T. 2019. E-learning platform/learning management system in education. International Journal of Reflective Researchin Social Sciences, 2(1), 64-66

[7] Kanuka, H., \& Anderson, T. (2007). Online social interchange, discord, and knowledge construction. International Journal of E-learning \& Distance Education, 13(1), 57-74.

[8] Leedy, P. D., \& Ormrod, J. P. (2005). Practical research-planning and design 8th Edn Pearson. Upper Saddle River, NJ.

[9] Means, B., Toyama, Y., Murphy, R., Bakia, M., \& Jones, K. (2010). Evaluation of evidence-based practices in online learning: A metaanalysis and review of online learning. Center for Technology in Learning, US Department of Education. Retrieved from http://www. ed. gov/about/offices/list/opepd/ppss/reports. html.

[10] Naidu, S. (2006). E-learning: A guidebook of principles, procedures and practices. Commonwealth Educational Media Centre for Asia (CEMCA).

[11] Sun, P. C., Tsai, R. J., Finger, G., Chen, Y. Y., \& Yeh, D. 2008. What drives a successful e-learning? An empirical investigation of the critical factors influencing learnersatisfaction. Computers \& Education, 50(4), 1183-1202.

[12] Thomson, L. D. 2010. Beyond the Classroom Walls:Teachers' and Students' Perspectives on How Online Learning Can Meet the Needsof Gifted Students. Journal of Advanced Academics, 21(4), 662-712).

[13] Wright, B. M. (2017). Blended learning: Student perception of face-to-face and online EFL lessons. Indonesian journal of applied linguistics, 7(1), 64-71.

[14] Xu, H., \& Ebojoh, O. (2007). Effectiveness of Online Learning Program: A Case Study of A Higher Education Institution. Issues in Information Systems, 8(1), 160.

[15] Zainuddin, Z., \& Keumala, C. M. (2018). Blended learning method within Indonesian higher education institutions. Jurnal Pendidikan Humaniora, 6(2), 69-77. 